Article

\title{
Antifungal Activity of Eclipta alba Metabolites against Sorghum Pathogens
}

\author{
Rajini Sollepura Boregowda ${ }^{1}$, Nandhini Murali ${ }^{1}$, Arakere C. Udayashankar ${ }^{1}$, \\ Siddapura R. Niranjana ${ }^{1}$, Ole S. Lund ${ }^{2}$ and Harischandra S. Prakash ${ }^{1, *}$ \\ 1 Department of Studies in Biotechnology, University of Mysore, Manasagangotri, Mysuru 570006, India; \\ rajinis16@gmail.com (R.S.B.); mnandhini2606@gmail.com (N.M.); ac.uday@gmail.com (A.C.U.); \\ niranjanasr@rediffmail.com (S.R.N.) \\ 2 Department of Plant and Environmental Science, University of Copenhagen, HøjbakkegårdAllé 13, \\ 2630 Taastrup, Denmark; osl@plen.ku.dk \\ * Correspondence: hasriprakash@gmail.com
}

Received: 12 February 2019; Accepted: 19 March 2019; Published: 22 March 2019

\begin{abstract}
Unscientific use of synthetic fungicides in plant disease management has environmental ramifications, such as disease resurgence and serious health problems due to their carcinogenicity. This has prompted the identification and development of eco-friendly greener alternatives. Eclipta alba extract was evaluated for its antifungal activity in in vitro and in vivo against sorghum fungal pathogens Fusarium thapsinum, Alternaria alternata, Epicoccum sorghinum, and Curvularia lunata. The column purified methanolic extract of E. alba exhibited good antifungal activity against the target pathogens. The MIC was observed at $80 \mathrm{mg} / \mathrm{mL}$ for all tested pathogenic fungi, whereas MFC was $80 \mathrm{mg} / \mathrm{mL}$ for E. sorghinum, $100 \mathrm{mg} / \mathrm{mL}$ for F. thapsinum, A. alternata, and C. lunata. In vitro germination percentage was significantly high in seeds treated with $E$. alba extract $(98 \%)$ over untreated control (91\%). Significant disease protection of 95\% was observed in greenhouse and $66 \%$ disease protection was noticed in field experiments. The efficacy of E. alba extract in field conditions was improved with the use of E. alba extract formulation. The profile of phytochemicals in E. alba methanol fractions was obtained by ultra-performance liquid chromatography (UPLC) mass spectroscopy. The $[\mathrm{M}-\mathrm{H}]^{-}$at $m / z 313.3, m / z$ 797.9, and $m / z 269.0$ revealed the presence of wedelolactone, eclalbasaponin II, and apigenin, respectively. The H-nuclear magnetic resonance spectroscopy $\left({ }^{1} \mathrm{H}-\mathrm{NMR}\right)$ chemical shift value supported the findings of the mass spectrometry. The results highlighted the possible use of E. alba methanolic extract as alternative to chemical fungicide in sorghum disease management.
\end{abstract}

Keywords: Eclipta alba; eclalbasaponin; sorghum pathogens; MIC; mass spectrometry

\section{Introduction}

The unmethodical usage of chemical fungicides for plant disease management has ecological implications, such as disease resurgence due to development of resistance in the target pathogens, and poses pollution problems. The repeated use of synthetic fungicides led to resistance in target pathogens with serious health problems in humans and animals due to their carcinogenicity, teratogenicity, and acute toxicity [1]. This has prompted a need for the investigation of alternative measures for crop disease management. So far, relatively very few botanical formulations have been registered and commercialized. The pharmacological and antimicrobial importance of aqueous and solvent extracts of Eclipta alba has been reviewed extensively [2,3]. The safety of E. alba extract was confirmed by preclinical toxicology studies using acute oral toxicity, eye irritation tests, and dermal irritation on New Zealand white rabbits and Sprague dawley rats [4]. 
Eclipta alba (L.) is an annual herbaceous plant, commonly known by the name 'False daisy' placed under Asteraceae family. E. alba is extensively used in Indian the traditional ayurvedic medicine system. E. alba has been used for the treatment of skin diseases, liver diseases, hair treatment and also as an antimicrobial, analgesic, anti-haemorrhagic, anti-hyperglycemic, and antioxidant agent [5]. E. alba contains a wide range of active metabolites, such as coumestans, triterpenoid saponins, flavonoids, alkaloids, and a glucoside of a triterpenic acid [6].

Sorghum is an important staple crop of semi-arid regions of world, especially in India and Africa. Grain mold caused by Fusarium thapsinum, Alternaria alternata, Epicoccum sorghinum, and Curvularia lunata is a destructive disease in sorghum. The pathogenic fungi also spoil the nutritive value of the grains by producing mycotoxins [7]. The fungal infection leads to heavy loss in grain yield as well rendering the grain unfit for human consumption [8,9]. The fungal infection mainly results in seed discoloration, loss in seed germination, seedling growth and overall field stand [10]. Aflatoxin, ochratoxin, and zearalenone are the major mycotoxins contaminating sorghum seeds [11]. Zearalenone, fumonisins, trichothecenes, and fusariotoxins produced by Fusarium spp. cause an adverse impact on human health. Zearalenone has been reported to have adverse effects on the reproductive system in animals and causes cancer in human. The mycotoxin produced by the genus of Alternaria induces mutagenesis in mammalian cells and causes gastrointestinal haemorrhage in animals [12]. The cytochalasins produced by Curvularia and Epicoccum species inhibit cytokinesis, protein synthesis, and induce brain oedema and pulmonary haemorrhaging in mice [13]. Currently, infestation of these economically destructive pathogenic fungi in sorghum is managed by chemical fungicides. Even though the long-term use of chemical fungicides induces tolerance in pathogens, carcinogenic health risks, toxicity on non-target organisms, and environmental pollution, farmers are inevitably using the expensive chemical fungicides.

The current study was intended to explore the antifungal potential of $E$. alba in vitro on economically destructive sorghum grain mold pathogens, such as F. thapsinum, A. alternata, E. sorghinum, and C. lunata. We have also evaluated the effect of E. alba extract treatment on in vitro germination and seedling emergence in vivo, and disease incidence and growth parameters under greenhouse conditions. Further, the phytochemicals in antifungal fractions of $E$. alba extract were characterized by ultra-performance liquid chromatography (UPLC) coupled triple quadrupole mass spectrometry (UPLC-MS/MS) and ${ }^{1} \mathrm{H}-\mathrm{NMR}$.

\section{Materials and Methods}

\subsection{Chemicals}

Hexane, ethyl acetate, methanol, and formic acid solvents were procured from Hi-Media Laboratories, Mumbai, India.

\subsection{Plant Collection and Identification}

Fresh matured E. alba plants were collected from paddy fields and humid sites with an annual humidity of $75 \%$ and insolation $5.45 \mathrm{kWh} / \mathrm{m}^{2} /$ day in the vicinity of Mysore $\left(12.2958^{\circ} \mathrm{N}, 76.6394^{\circ} \mathrm{E}\right)$, Karnataka. The plant was taxonomically identified by Dr. K. K. Sampath Kumara, Taxonomist.

\subsection{Extraction of E. alba}

The aerial parts of E. alba were separated from wild plants, washed thoroughly 5 to 6 times with running tap water and shade dried at room temperature for 15 days, then pulverized to a fine powder. Thirty grams of the powdered sample was placed in soxhlet extractor and sequentially extracted with $250 \mathrm{~mL}$ each of hexane, ethyl acetate, methanol, and water $\left(50-85^{\circ} \mathrm{C}\right)$. Extracts were concentrated under low vacuum by using rotary evaporator (Buchi Rotavapor, R-205). The dried extracts were collected and stored as aliquots at $4{ }^{\circ} \mathrm{C}$ for further analysis. 


\subsection{Isolation of Fungi}

The seed borne fungi were detected by the standard blotter method [14]. Farm-saved sorghum seeds originating from the agro-ecological zones of Karnataka were used for the isolation of fungi. The fungal colonies on incubated sorghum seeds were isolated separately, each fungus was further cultured on potato dextrose agar (PDA) plates and incubated at $27{ }^{\circ} \mathrm{C}$ for a period of 7 days. The pathogens were identified based on conidial and morphological characteristics. The authenticity of target pathogens was confirmed by Internal transcribed spacer (ITS) sequences Acc. No. F. thapsinum KX155571, E. sorghinum KY499205, C. lunata KY499208, and A. alternata KY674986.

\subsection{In Vitro Antifungal Activity of Methanolic Extract and Column Purified Fraction}

\subsubsection{Agar Well Diffusion Assay}

Antifungal activity of different solvent extracts was determined by the agar well diffusion method. One hundred microliters of fungal spore suspension containing $F$. thapsinum, E. sorghinum, C. lunata, and A. alternata at $10^{6}$ spores $/ \mathrm{mL}$ concentration was spread on solidified PDA medium. The wells were punched using $5 \mathrm{~mm}$ cork borer and loaded with $100 \mu \mathrm{L}$ DMSO containing $20 \mathrm{mg} / \mathrm{mL}$ to $120 \mathrm{mg} / \mathrm{mL}$ extracts. Wells loaded with solvent alone served as negative control. Positive control include wells loaded with synthetic fungicide Bavistin $(1 \mathrm{mg} / \mathrm{mL})$. All the plates were incubated for 7 days and the diameter of inhibition zone of test microorganism was measured in millimeters. All the experiments were performed in triplicate.

\subsubsection{Minimum Inhibitory Concentration and Minimum Fungicidal Concentration}

Broth microdilution method was carried out to evaluate the minimum inhibitory concentration (MIC) and minimum fungicidal concentration (MFC) of E. alba methanol extract [15]. Potato dextrose broth (PDB) was added with the required concentration of E. alba methanol extracts dissolved in DMSO to obtain the range of concentrations from $20 \mathrm{mg} / \mathrm{mL}$ to $120 \mathrm{mg} / \mathrm{mL}$. Ten micorliters of pathogen spore suspension $\left(1 \times 10^{6}\right.$ spores $\left./ \mathrm{mL}\right)$ was inoculated to each flask and incubated for 7 days at $24 \pm 2{ }^{\circ} \mathrm{C}$. Control flasks with PDB were inoculated only with pathogen spore suspension and neat DMSO. The least concentration at which no visible growth observed was considered as MIC. Fungal spores from the flasks showing no growth were sub-cultured on new PDA plates to determine the MFC. If the inhibition was reversible, then the extract concentration was considered to have no fungicidal action. MFC is the lowest concentration at which no fungal growth was observed on PDA plates [16]. The experiment was repeated twice with three replications per concentration.

\subsubsection{Microtiter Plate Assay}

The antifungal activity of purified E. alba extract was determined using sterile 96 well plates. The cell densities were determined using tetrazolium dye MTT [3-(4,5-dimethyl-thiazol-2-yl) 2,5-diphenyl tetrazolium bromide] at A570 nm. The 12 wells of each row were filled with $200 \mu \mathrm{L}$ of PDB (24 g/L, Himedia, India) containing $2 \times 10^{6}$ fungal spores $/ \mathrm{mL}$ and $10 \mu \mathrm{L}$ of MTT $(2 \mathrm{mg} / \mathrm{mL})$. An aliquot of $40 \mu \mathrm{L}$ from the stock solution of E. alba extract was transferred to the wells to obtain a final concentration of $20 \mu \mathrm{g} / \mathrm{mL}$ to $120 \mu \mathrm{g} / \mathrm{mL}$. The wells that received $40 \mu \mathrm{L}$ of DMSO served as negative control and wells with Bavistin $(1 \mu \mathrm{g} / \mathrm{mL})$ were considered as positive control. The fungal spores were allowed to settle for $30 \mathrm{~min}$ and the plates were incubated for $48 \mathrm{~h}$. The resulting turbidity was measured at A570 $\mathrm{nm}$ after $30 \mathrm{~min}$ and $48 \mathrm{~h}$ at A570 $\mathrm{nm}$ using Tecan infinite M200PRO ELISA plate reader [17]. The antifungal activity was expressed in terms of percent growth inhibition and the extract concentration that exhibits 50\% growth inhibition is considered as MIC.

$$
\text { Percent growth inhibition }=\frac{\text { Corrected A570 } \mathrm{nm} \text { of control }- \text { Corrected A570 nm of the E.alba extract }}{\text { corrected A570 } \mathrm{nm} \text { of the control }} \times 100
$$


where, corrected A570 nm $=\mathrm{A} 570 \mathrm{~nm}$ of the culture measured after $48 \mathrm{~h}-$ the A570 $\mathrm{nm}$ measured after $30 \mathrm{~min}$.

\subsubsection{In Vitro Germination Test}

The effect of E. alba extract on germination of sorghum seeds was tested. Three replicates of 100 seeds were inoculated with target pathogen F. thapsinum, E. sorghinum, A. alternata, and C. lunata by soaking seeds for $6 \mathrm{~h}$ in a solution containing respective fungal spores at $1 \times 10^{7}$ spores $/ \mathrm{mL}$ concentration. The inoculated seeds were treated with $120 \mathrm{mg} / \mathrm{mL}$ E. alba extract. The seeds that received only pathogen inoculation, uninoculated seeds, and Bavistin $(1 \mathrm{mg} / \mathrm{mL})$ served as controls.

The between paper method was used for evaluating the germination rate. The seeds were placed between two layers of moist paper towels and kept for incubation. The germination percentage of sorghum seeds was calculated after 10 days of inoculation [18].

\subsection{Greenhouse Experiment}

A greenhouse experiment was conducted to evaluate the effect of E. alba extract on seedling emergence, disease incidence, and seedling growth parameters. Sixty sorghum seeds were inoculated separately by soaking each in a solution containing $1 \times 10^{7}$ spores $/ \mathrm{mL}$ of $F$. thapsinum, E. sorghinum, A. alternata, and C. lunata. The inoculated seeds were treated with $120 \mathrm{mg} / \mathrm{mL}$ E. alba extract. The uninoculated seeds, seeds inoculated with only pathogens, and seeds treated with Bavistin $(1 \mathrm{mg} / \mathrm{mL})$ were used as controls.

The 20 treated seeds from each treatment were sown in a plastic pot containing a sterilized mixture of red soil: clay soil: compost (1:1:1) proportion collected randomly from experimental plots of the Department of Science (DOS) in Biotechnology, University of Mysore Karnataka. India. The pots were maintained under greenhouse conditions for 10 days at $25^{\circ} \mathrm{C}$ to $29^{\circ} \mathrm{C}$. A completely randomized design (CRD) was used with three replications. The seedling emergence and the disease incidence based on the visual symptoms, such as chlorotic straw-colored elliptical lesions on leaves (E. sorghinum), pale lesions with dark brownish red borders on leaves (A. alternata), wilt and visual stunted growth (F. thapsinum) and reddish brown circular spots on the leaves (C. lunata), were evaluated at ten days after sowing. The growth parameters, such as shoot length and root length, shoot and root dry weight, were recorded at 30 days after sowing.

\subsection{Field Trials}

Field trials were conducted during Kharif season (rainy season-July to October) in experimental plots of the DOS in Biotechnology, University of Mysore, India. Sorghum seeds were soaked in different concentrations of E. alba extract in a rotary shaker at $25 \pm 2{ }^{\circ} \mathrm{C}$ for $6 \mathrm{~h}$. The suspended seeds were dried overnight. Seeds were again soaked in a suspension of the pathogen $\left(10^{7}\right.$ spores $\left./ \mathrm{mL}\right)$ for $3 \mathrm{~h}$ and dried overnight. Seeds soaked in distilled water for the $6 \mathrm{~h}$ served as negative control. Seeds usted with Bavistin ( $3 \mathrm{~g} / \mathrm{kg}$ seed) served as positive control. The treated seeds were hand sown in the experimental plot consisting of seven rows five meters long, $60 \mathrm{~cm}$ distant, and $20 \mathrm{~cm}$ of intra-row spacing with two replications per treatment. The seedling emergence was recorded at 10 days after sowing (DAS), and disease incidence was recorded at 30 DAS, and final counts were made at 60 DAS. At maturity, visual disease observation was taken, and the seed weight was measured as the weight of 1000 kernels from each panicle [19].

\subsection{Formulation of E. alba Fungicide}

E. alba methanolic extract formulation was prepared to facilitate ease of application, handling, application, uniformity, sustained release, and penetration by using Xanthan gum (1\%), suspending agent $(8 \%)$, Potassium sorbate $(0.5 \%)$, alkyl phenyl ethoxylate $(3 \%)$, defoaming agent $(0.5 \%)$, E. alba methanol extract $(15 \%)$, and the required amount of water. 


\subsection{Characterization of E. alba Extract}

\subsubsection{TLC Profiling of Crude Extract}

The chromatographic profiling of crude extract was done by thin layer chromatography (TLC). A combination of Hexane: ethyl acetate: formic acid (8:2:0.5) was used as the mobile phase. Samples of the crude extract and reference standard (eclalbasaponin II and wedelolactone) were spotted on to the chromatographic plate (GF 254 60; Merck $20 \mathrm{~mm} \times 20 \mathrm{~mm}$ thick, Darmstadt, Germany) with glass capillary tubes and eluted with the mobile phase. Plates were observed under UV $254 \mathrm{~nm}$ and photographed. Further, the spots were developed using a reagent mixture containing p-anisaldehyde $(2 \% v / v)$ and sulfuric acid $(5 \% v / v)$ in methanol. The retention factor $(\mathrm{Rf})$ values of all the spots were determined and tabulated.

\subsubsection{Column Purification of Crude Extract}

The crude extract was further purified by passing it through a silica gel column. About $4 \mathrm{~g}$ methanolic crude was redissolved in $5 \mathrm{~mL}$ of methanol and loaded to columns $(3.6 \mathrm{~cm} \times 50 \mathrm{~cm})$ packed with activated silica gel ( $30 \mathrm{~g}, 60-200$ mesh size) using hexane. The column was then eluted sequentially with $100 \mathrm{~mL}$ of hexane, ethyl acetate, and methanol at $3 \mathrm{~mL} / \mathrm{min}$ of flow rate. Twenty-five milliliters of each fraction were pooled and concentrated to $5 \mathrm{~mL}$ using a Buchi Rotavapor. The concentrated fractions were checked for antifungal activity against target pathogens using a disk diffusion assay. Fractions which showed antifungal activity were combined and concentrated. The antifungal fraction was further analyzed by ultra-performance liquid chromatography (UPLC).

\subsubsection{UPLC-Diode Array Detector (UPLC-DAD)}

The chromatographic profiling of crude methanolic extract and the antifungal fraction was done by reverse phase liquid chromatography (Agilent 1290A series) UPLC equipped with a binary pump, automatic injector and an ultraviolet diode array detector (UV/DAD) module. Separation was accomplished on ACQUITY UPLC HSS T3 column $(100 \mathrm{~mm} \times 2.1 \mathrm{~mm}, 1.6 \mu \mathrm{m}$, Waters $)$ using Acetonitrile (A) and water containing $0.1 \% \mathrm{HCOOH}(\mathrm{B})$. The following gradient elution system was used: 0-15 $\mathrm{min}, 20-30 \%$ A; $15-28 \mathrm{~min}, 30 \%$ A; $28-30 \mathrm{~min}, 30-40 \%$ A; 30-38 min, 40\% A; 38-45 min, $40-100 \%$ A; $45-50 \mathrm{~min}, 100-100 \%$ A; 50-50.5 min, 10\% A; 50.5-60 min, 10\% A. An injection volume of $5 \mu \mathrm{L}$ and a flow rate of $0.3 \mathrm{~mL} / \mathrm{min}$ were adjusted and the column temperature was set at $30{ }^{\circ} \mathrm{C}$. The spectrum was read at $260 \mathrm{~nm}$ UV and the chromatograph profiles of compounds are represented.

\subsubsection{UPLC Triple Quadrupole MS/MS}

The chromatographic characterization of antifungal column purified sample was performed by Agilent 1290A UPLC consisting of a binary pump, a diode-array detector, an auto sampler, and a column thermostat connected to an Agilent 6590 Q3 mass spectrometry via an electrospray ionization (ESI) interface (Agilent Corp., Santa Clara, CA, USA). The UPLC conditions were the same as explained above.

A full-scan analysis in negative ionization mode was conducted, and the spectra were recorded in the range of $m / z 100$ to $m / z$ 1700. The major parameters used were as follows: drying gas with a flow rate of $8.0 \mathrm{~L} / \mathrm{min}$, drying gas temperature $350{ }^{\circ} \mathrm{C}$, nebulizer $30 \mathrm{psig}$, capillary voltage $3500 \mathrm{~V}$ and fragmentor voltage $175 \mathrm{~V}$. The peak abundance of the identified mass was recorded. The identification and characterization of prominent compounds were performed based on the fragmentation pattern.

\subsubsection{H-Nuclear Magnetic Resonance Spectroscopy}

The H-nuclear magnetic resonance spectroscopy $\left({ }^{1} \mathrm{H}-\mathrm{NMR}\right)$ characterization of the antifungal column purified sample was carried out using ${ }^{1} \mathrm{H}-\mathrm{NMR}$ Spectrometer (DDR X—400 $\mathrm{m} / \mathrm{z}$ Bruker 
Deltonics, Germany) using deuterated DMSO as a solvent and the functional groups present in the extract were determined.

\subsection{Statistical Analysis}

The analysis of variance (ANOVA) was performed using OPSTAT software. Mean values among treatments were compared by the least significant difference using critical difference (CD) at a 95 percent level of confidence $(p<0.05)$.

\section{Results}

The present study was designed with the intension of identifying a greener, safer, effective, and economically affordable botanical fungicide. The dried E. alba powder was sequentially extracted with hexane, ethyl acetate, methanol, and water using the soxhlet extraction process. The antifungal activity of E. alba crude solvent extracts was evaluated by the agar well diffusion method. The methanol extract exhibited the highest antifungal activity with a maximum of $6.0 \mathrm{~mm}$ inhibition of E. sorghinum at $80 \mathrm{mg} / \mathrm{mL}$ followed by $F$. thapsinum $(5.8 \mathrm{~mm})$ at $120 \mathrm{mg} / \mathrm{mL}$, whereas A. alternata $(5.9 \mathrm{~mm})$, and C. lunata $(5.9 \mathrm{~mm})$ were inhibited at $100 \mathrm{mg} / \mathrm{mL}$. The synthetic fungicide Bavistin at $1 \mathrm{mg} / \mathrm{mL}$ showed highest antifungal activity against E. sorghinum, followed by F. thapsinum, A. alternata, and C. lunata (Table 1 and Figure 1).

Table 1. Antifungal activity of methanolic extract of Eclipta alba (Agar well diffusion assay).

\begin{tabular}{|c|c|c|c|c|}
\hline \multirow[b]{2}{*}{ Target Pathogens } & \multicolumn{4}{|c|}{ Zone of Inhibition (mm) } \\
\hline & F. thapsinum $\$$ & E. sorghinum $\$$ & A. alternata $\$$ & C. lunata $\$$ \\
\hline Methanolic crude extract $(120 \mathrm{mg} / \mathrm{mL})$ & 5.8 & 6 & 5.9 & 5.9 \\
\hline Purified extract (120 mg/mL) & 6.2 & 6.8 & 6.6 & 6.5 \\
\hline Bavistin $(1 \mathrm{mg} / \mathrm{mL})$ & 7.3 & 6.9 & 7 & 7.1 \\
\hline Mean & 6.4 & 6.6 & 6.5 & 6.5 \\
\hline SD & \pm 2.8 & \pm 2.9 & \pm 2.8 & \pm 2.7 \\
\hline${ }^{*} \mathrm{CD}\left(0.05^{\#}\right)$ & 0.29 & 0.22 & 0.24 & 0.56 \\
\hline
\end{tabular}

*CD—critical difference, SD—Standard deviation, ${ }^{\#} \_5 \%$ level of Significance, ${ }^{\$}$ - Three replications.

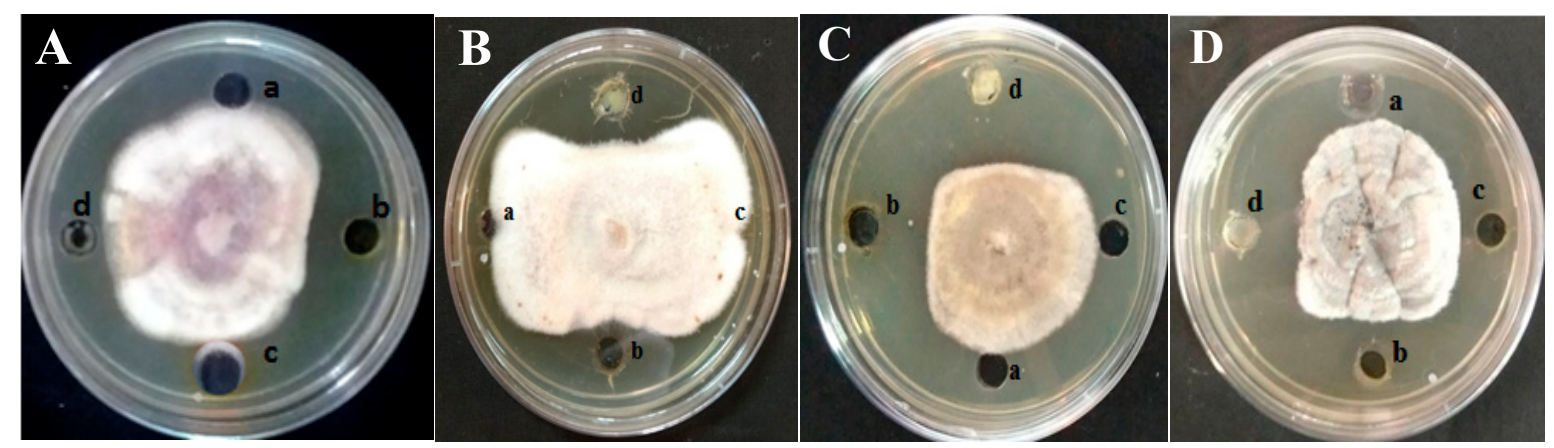

Figure 1. Growth inhibition of (A) Fusarium thapsinum, (B) Epicoccum sorghinum, (C) Alternaria alternata and (D) Curvularia lunata pathogens by crude methanolic extract of Eclipta alba at $120 \mathrm{mg} / \mathrm{mL}$ concentration. (a) Control, (b) Methanolic extract of E. alba, (c) DMSO, (d) Bavistin.

The crude methanol extract was further purified to differential polarity fractions of hexane, ethyl acetate, and methanol fractions using silica columns and tested for antifungal activity by the agar well diffusion method. The zone of inhibition for F. thapsinum was $6.2 \mathrm{~mm}$ at $120 \mathrm{mg} / \mathrm{mL}, 6.8 \mathrm{~mm}$ for E. sorghinum at $80 \mathrm{mg} / \mathrm{mL}, 6.6 \mathrm{~mm}$ for A. Alternata, and $6.5 \mathrm{~mm}$ at $100 \mathrm{mg} / \mathrm{mL}$ for C. lunata (Figure 2). Further, the MIC was carried out by the broth macro-dilution method and the microspectrophotometric method. MIC was observed at $80 \mathrm{mg} / \mathrm{mL}$ for all the tested pathogenic fungi. The MFC was $80 \mathrm{mg} / \mathrm{mL}$ for E. sorghinum and $100 \mathrm{mg} / \mathrm{mL}$ for F. thapsinum, C. lunata, and A. alternata. The MIC determined by 
the microspectrophotometric method was represented as a percentage of microbial inhibition. $50 \%$ growth inhibition for E. sorghinum, F. thapsinum, C. lunata, and A. alternata was observed at $60 \mathrm{mg} / \mathrm{mL}$ of E. alba extract (Table 2).

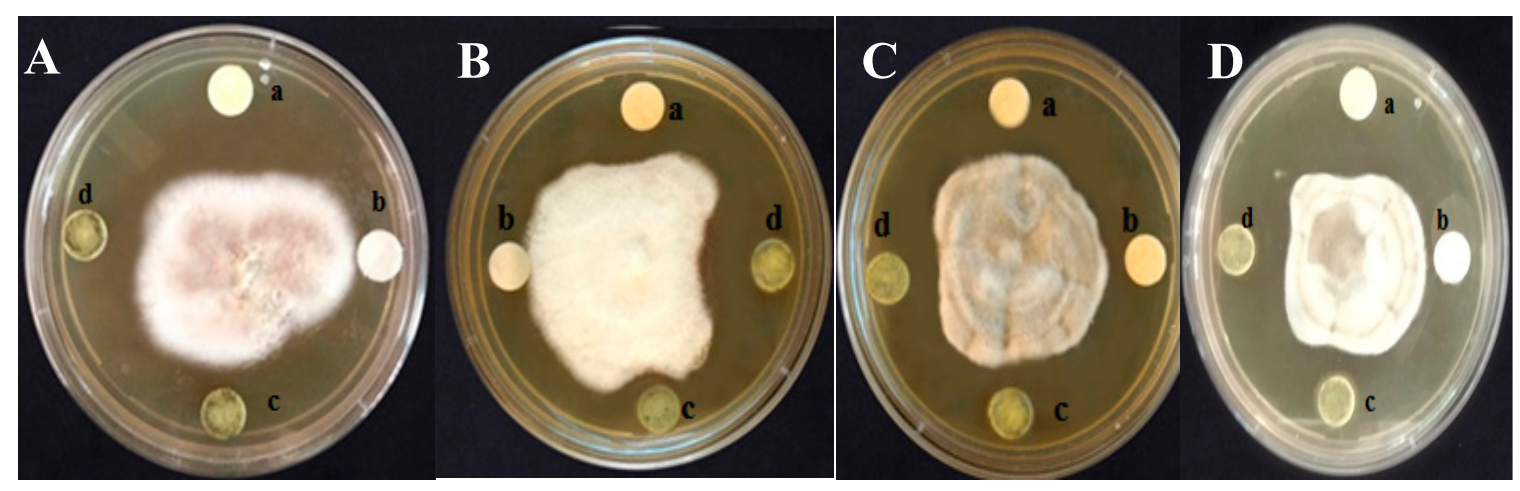

Figure 2. Growth inhibition of (A) F. thapsinum, (B) E. sorghinum, (C) A. alternata and (D) C. lunata pathogens were observed by column purified fraction of methanolic extract of E. alba. (a) Bavistin, (b) Control, (c) Ethyl acetate fraction, (d) Purified fraction of Methanolic extract of E. alba.

Table 2. Percentage growth inhibition exhibited by E. alba extract by Microtiter plate assay.

\begin{tabular}{|c|c|c|c|c|}
\hline \multirow[b]{2}{*}{$\begin{array}{l}\text { Concentration of } E \text {. alba } \\
\text { Extract }(\mu \mathrm{g} / \mathrm{mL})\end{array}$} & \multicolumn{4}{|c|}{ Target Pathogens (Percent Growth Inhibition) } \\
\hline & F. thapsinum & E. sorghinum & A. alternata & C. lunata \\
\hline 20 & 34 & 34 & 33 & 30 \\
\hline 40 & 42 & 46 & 41 & 48 \\
\hline 60 & 52 & 64 & 56 & 63 \\
\hline 80 & 73 & 74 & 69 & 74 \\
\hline 100 & 80 & 82 & 86 & 83 \\
\hline 120 & 86 & 87 & 89 & 88 \\
\hline Bavistin $(1 \mu \mathrm{g} / \mathrm{mL})$ & 91 & 91 & 94 & 93 \\
\hline Mean & 65 & 68 & 67 & 68 \\
\hline $\mathrm{SD}$ & \pm 1.91 & \pm 6 & \pm 3 & \pm 3 \\
\hline${ }^{*} \mathrm{CD}\left(0.05^{\#}\right)$ & 2.11 & 2.32 & 2.38 & 2.05 \\
\hline
\end{tabular}

${ }^{*} \mathrm{CD}$-critical difference, SD—standard deviation, ${ }^{\#-5 \%}$ level of Significance.

The germination percentage of the infected seeds upon treatment with E. alba extract was $98 \%$, which was significantly higher than seeds inoculated with $F$. thapsinum $77 \%$, A. alternata $76 \%$, E. sorghinum $78 \%$, C. lunata $76 \%$ and uninoculated seeds $92 \%$ (Table 3 ). Seedling emergence (\%) under greenhouse conditions was significantly influenced by target pathogens. The seed inoculated with F. thapsinum reduced the seedling emergence to $68 \%$ followed by A. alternata $70 \%$, C. lunata $72 \%$, and E. sorghinum $75 \%$. However, a significantly higher seedling emergence of $98 \%$ was recorded in seeds treated with E. alba extract (Supplementary Figure S1), compared to control (Table 3). The percentage of infected seedlings at 10 and 30 days after inoculation was significantly higher in F. thapsinum (62\%) followed by C. lunata (61\%), A. alternata (60\%), and E. sorghinum (58\%). Whereas when seeds received E. alba treatment, it significantly reduced the infection by $90 \%$ compared to untreated infected seeds (Table 3$)$. Significantly higher shoot length $(32 \mathrm{~cm})$, root length $(10 \mathrm{~cm})$, shoot dry weight $(2 \mathrm{~g})$, and root dry weight $(0.17 \mathrm{~g})$ were noticed in the E. alba treated seeds over untreated control. 
Table 3. Influence of purified E. alba methanol extract on sorghum pathogens and growth parameters under greenhouse condition.

\begin{tabular}{|c|c|c|c|c|c|c|c|c|}
\hline Treatment & $\begin{array}{c}\text { In vitro } \\
\text { Germination. } \\
(\%)\end{array}$ & $\begin{array}{c}\text { Seedling } \\
\text { Emergence } \\
\text { Rate (\%) }\end{array}$ & $\begin{array}{c}\text { Disease } \\
\text { Incidence at } \\
\text { 10th Day }\end{array}$ & $\begin{array}{c}\text { Disease } \\
\text { Incidence at } \\
\text { 30th Day }\end{array}$ & $\begin{array}{c}\text { Shoot } \\
\text { Length }(\mathrm{cm})\end{array}$ & $\begin{array}{c}\text { Root } \\
\text { Length }(\mathrm{cm})\end{array}$ & $\begin{array}{l}\text { Dry Shoot } \\
\text { Weight (g) }\end{array}$ & $\begin{array}{l}\text { Dry Root } \\
\text { Weight (g) }\end{array}$ \\
\hline Control & 92 & 84 & 34 & 36 & 23.30 & 6.80 & 1.15 & 0.10 \\
\hline F. thapsinum & 77 & 68 & 62 & 66 & 11.87 & 5.60 & 0.82 & 0.10 \\
\hline E. sorghinum & 78 & 75 & 58 & 61 & 11.93 & 4.60 & 0.84 & 0.10 \\
\hline A. alternata & 76 & 70 & 60 & 62 & 11.97 & 4.33 & 0.75 & 0.10 \\
\hline C. lunata & 76 & 72 & 61 & 66 & 11.57 & 4.17 & 0.67 & 0.10 \\
\hline E. alba extract $+F$. thapsinum & 99 & 97 & 5 & 11 & 30.67 & 10.50 & 2.10 & 0.18 \\
\hline E. alba extract $+E$. sorghinum & 99 & 98 & 9 & 9 & 31.23 & 10.67 & 2.12 & 0.18 \\
\hline$E$. alba extract $+A$. alternata & 97 & 99 & 15 & 15 & 33.97 & 9.37 & 2.04 & 0.16 \\
\hline E. alba extract $+C$. lunata & 98 & 98 & 5 & 5 & 33.93 & 9.03 & 2.13 & 0.17 \\
\hline Bavistin $+F$. thapsinum & 98 & 98 & 5 & 5 & 31.97 & 11.07 & 2.08 & 0.18 \\
\hline Bavistin + E. sorghinum & 97 & 99 & 9 & 9 & 30.37 & 10.17 & 2.16 & 0.18 \\
\hline Bavistin + A. alternata & 98 & 99 & 1 & 1 & 32.90 & 10.80 & 2.01 & 0.15 \\
\hline Bavistin + C. lunata & 99 & 97 & 1 & 1 & 33.67 & 9.43 & 2.07 & 0.15 \\
\hline E. alba extract & 98 & 98 & 4 & 5 & 31.45 & 10.9 & 2.12 & 0.17 \\
\hline Bavistin & 99 & 99 & 1 & 1 & 33.98 & 11.12 & 2.18 & 0.18 \\
\hline Mean & 92.07 & 90.07 & 22.00 & 23.53 & 26.32 & 8.57 & 1.68 & 0.15 \\
\hline SD & \pm 9.72 & \pm 12.38 & \pm 25.22 & \pm 26.53 & \pm 9.41 & \pm 2.68 & \pm 0.62 & \pm 0.04 \\
\hline${ }^{*} \mathrm{CD}\left(0.05^{\#}\right)$ & 4.37 & 5.36 & 8.11 & 8.03 & 1.68 & 1.31 & 0.18 & 0.03 \\
\hline
\end{tabular}

${ }^{*} \mathrm{CD}$-critical difference. $\%$-percentage. cm—centimeter. g—gram. ${ }^{\#-5 \%}$ level of Significance. 
The field trial results showed a significant improvement in the seedling emergence of $98 \%$ in the seeds treated with E. alba extract compared to that of negative control (84\%). Significantly higher disease protection of $66 \%$ was observed in the E. alba treated seed compared to control (44\%). 1000 seed weight was significantly higher in the E. alba treatment $(20.8 \mathrm{~g})$ compared to that of negative control (Table 4 and Supplementary Figure S2a,b).

Table 4. Influence of purified E. alba methanol extract on sorghum pathogens and growth parameters under field conditions.

\begin{tabular}{ccccccc}
\hline Treatment & $\begin{array}{c}\text { Disease } \\
\text { Protection at 60 } \\
\text { DAS (\%) }\end{array}$ & $\begin{array}{c}\text { \% of Emerged } \\
\text { Seedlings at 10 } \\
\text { DAS }\end{array}$ & $\begin{array}{c}\text { Plant } \\
\text { Length }\end{array}$ & $\begin{array}{c}\text { Panicle } \\
\text { Length (cm) }\end{array}$ & $\begin{array}{c}\text { Panicle } \\
\text { Width (cm) }\end{array}$ & $\begin{array}{c}\mathbf{1 0 0 0} \\
\text { Seed }\end{array}$ \\
\hline Control & 44 & 84 & 105 & 16.2 & 6 & 16.85 \\
F. thapsinum & 19 & 68 & 101 & 13.1 & 5.1 & 14.37 \\
E. sorghinum & 20 & 75 & 100 & 13 & 4.2 & 13.23 \\
A. alternata & 20 & 70 & 101 & 12.2 & 5.2 & 13.0 \\
C. lunata & 21 & 72 & 100 & 13.1 & 4.0 & 11.23 \\
E. alba extract & 66 & 99 & 110 & 17.0 & 6.4 & 20.8 \\
Pathogen suspension & 80 & 98 & 110 & 17.0 & 6.6 & 21.0 \\
E. alba extract & 89 & 98 & 112 & 19.0 & 6.7 & 21.2 \\
Bavistin & 44.9 & 83.0 & 104.9 & 15.1 & 5.53 & 16.5 \\
Mean & \pm 29.53 & \pm 13.55 & \pm 5.08 & \pm 2.52 & \pm 1.06 & \pm 4.07 \\
SD & 5.61 & 5.8 & 3.98 & 1.21 & 0.27 & 0.97 \\
CD $\left(p<0.05^{\#}\right)$ & & & & &
\end{tabular}

CD—critical difference, DAS—Days after sowing, ${ }^{\#}-5 \%$ level of Significance.

Phytochemicals in the methanol fraction of E. alba were studied using various chromatographic techniques such as TLC, UPLC-DAD, UPLC-MS/MS, and ${ }^{1} \mathrm{H}-\mathrm{NMR}$. The TLC revealed the presence of nine major spots with distinct Rf values (Figure 3). The chromatographic profile of crude extract and purified methanol fraction were obtained by UPLC reverse phase method. Nine major peaks were identified in the purified methanol fraction compared to 32 unidentified peaks in crude. The presence of three major categories of compounds, such as saponins, coumestans, and flavonoids, in column purified sample was confirmed based on the Relative Retention Time (RRT) with respect to wedelolactone (Table S1, Figures 4 and 5).

The more precise chemical identification and characterization of the major bioactive compounds were done by using UPLC triple quadrupole mass spectrometry with electrospray ionization (ESI) interface. Ten major compounds were identified, out of which four compounds could be identified as saponins, coumestans, and flavonoids based on MS features (Supplementary Figure S3). The identified compounds with their concentration (area abundance \%), and retention time (RT) are represented in Table 5 and Supplementary Figure S4.

Table 5. Percent abundance of the compounds in the column purified methanol fraction of E. alba analysed using ultra-performance liquid chromatography-mass spectroscopy (UPLC-MS/MS).

\begin{tabular}{ccccc}
\hline S1. No & RT & $\boldsymbol{m} / \boldsymbol{z}$ & Probable Compounds & \% Abundance \\
\hline 1 & 3.17 & 349.0 & Apigenin sulfate & 1.25 \\
2 & 8.91 & 447.0 & Luteolin-7-O- $\beta$-D glucoside & 0.37 \\
3 & 11.58 & 285.9 & Luteolin & 0.85 \\
4 & 11.58 & 364.9 & Luteolin sulfate & 0.45 \\
5 & 12.08 & 797.9 & Eclalbasaponin II & 17.20 \\
6 & 12.21 & 313.1 & Wedelolactone & 11.80 \\
7 & 13.56 & 269.0 & Apigenin & 6.41 \\
8 & 17.61 & 957.3 & Eclalbasaponin III & 0.17 \\
9 & 19.67 & 841.3 & Ecliptasaponin C & 2.01 \\
10 & 20.86 & 875.3 & Eclalbasaponin VI & 10.20 \\
\hline
\end{tabular}




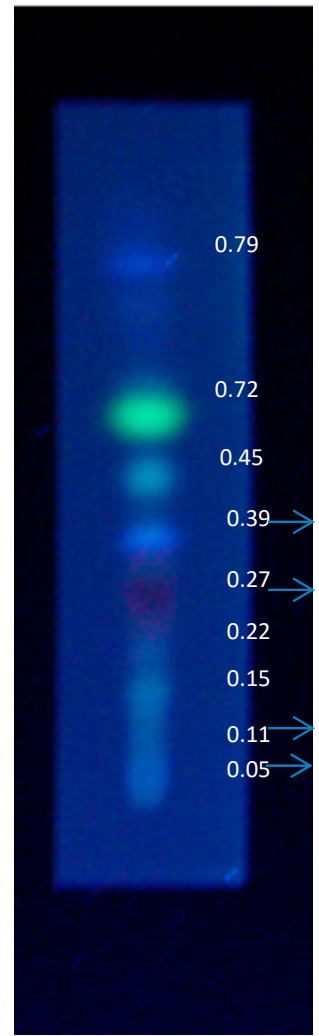

(A)

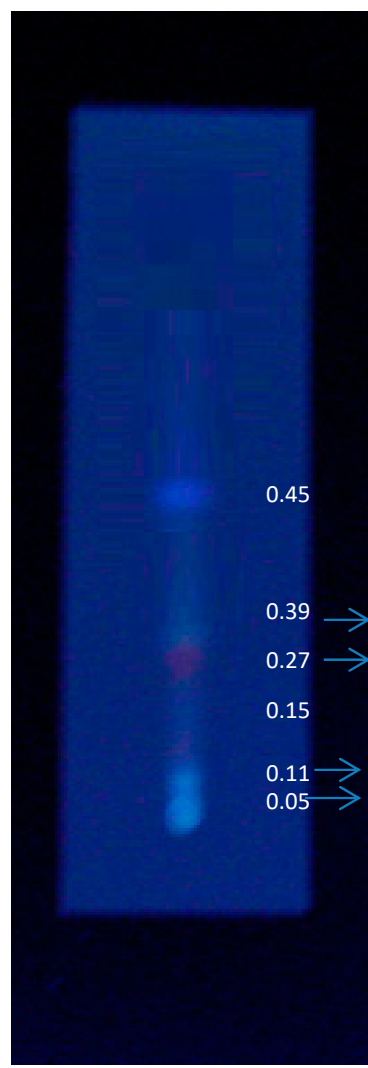

Eclalbasaponin I

Eclalbasaponin II

Eclalbasaponin III

Wedelolactone

(B)

Figure 3. Thin layer chromatography (TLC) profile of E. alba (A) methanolic crude and (B) column purified extract.

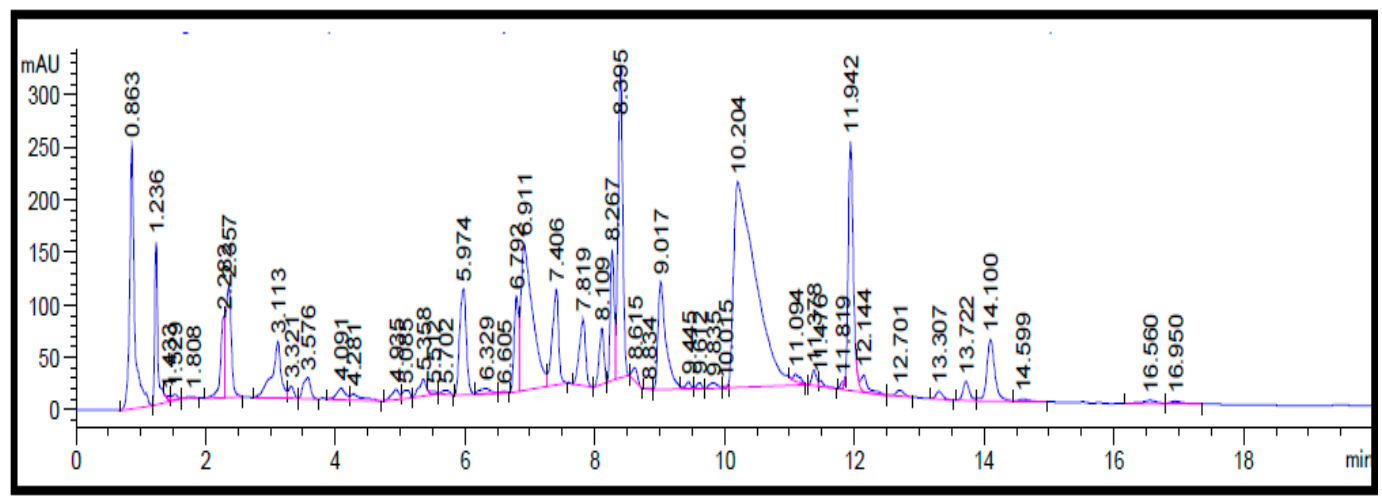

Figure 4. Ultra-performance liquid chromatography (UPLC) Chromatogram profile of E. alba crude extract at $260 \mathrm{~nm}$.

Based on the mass to charge ratio $(m / z)$, the compounds showed [M-H] $]^{-}$at $m / z 349$ and $m / z$ 269 which corresponds to apigenin sulfate and apigenin. Since the molecular masses of triterpenoid saponins are usually large, we used two collision energies (CE) for identification. The signals recorded at $m / z 797.9, m / z 841.3$, and $m / z 875.3$ were identified as [M-H] $]^{-}$corresponding to eclalbasaponin II, ecliptasaponin C, and eclalbasaponin VI, respectively. The wedelolactone was identified by comparing its retention time and $m / z$ value (313.1) with respect to the reference standard (Supplementary Figure S4). The compounds identified in MS were further confirmed by structural elucidation using $400 \mathrm{MHz}$ ${ }^{1} \mathrm{H}-\mathrm{NMR}$ (Figure 6). The singlets at $\delta 7.23,7.16 \mathrm{ppm}$ and doublets at $\delta 6.61,6.61 \mathrm{ppm}$ and 6.45 and $6.44 \mathrm{ppm}$ suggested the presence of phenolic compounds, such as wedelolactone, and flavonoids, 
such as apigenin. The spectrum presented one proton broad singlet at $\delta 5.19 \mathrm{ppm}$, which indicated the presence of olefins proton. Intensities of three protons with $\delta 0.68,0.75,0.83,0.86,0.90,0.97$ singlets and $1.31 \mathrm{ppm}$ indicated the presence of tertiary methyl groups and a proton signal at $\delta 4.32$ revealed the presence of the glucose moiety of eclalbasaponins.

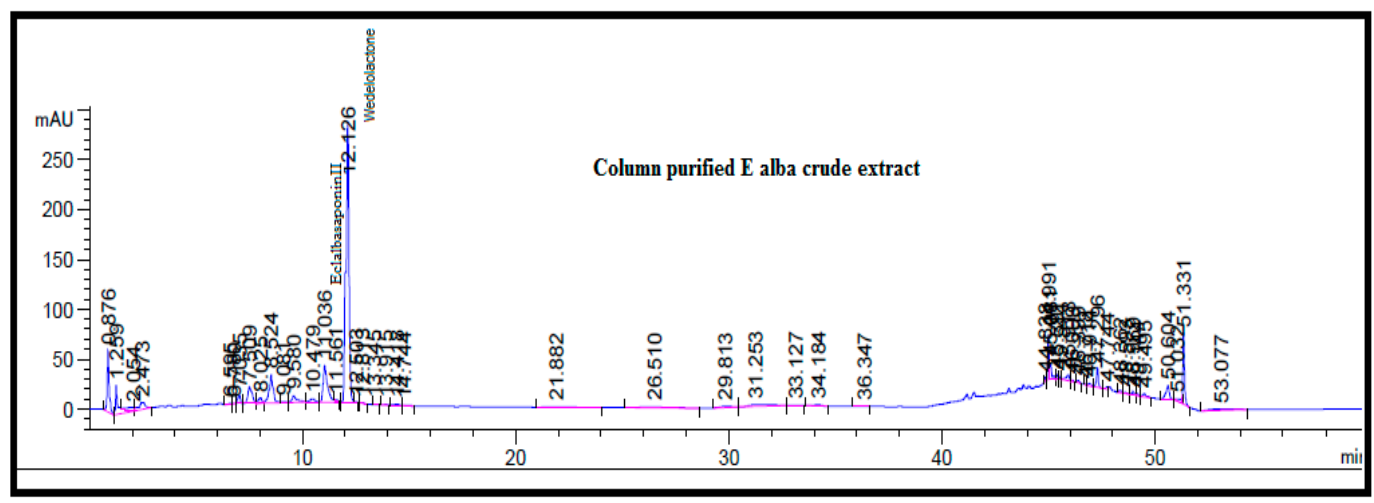

Figure 5. UPLC chromatogram profile of the column purified fraction of E. alba at $260 \mathrm{~nm}$.

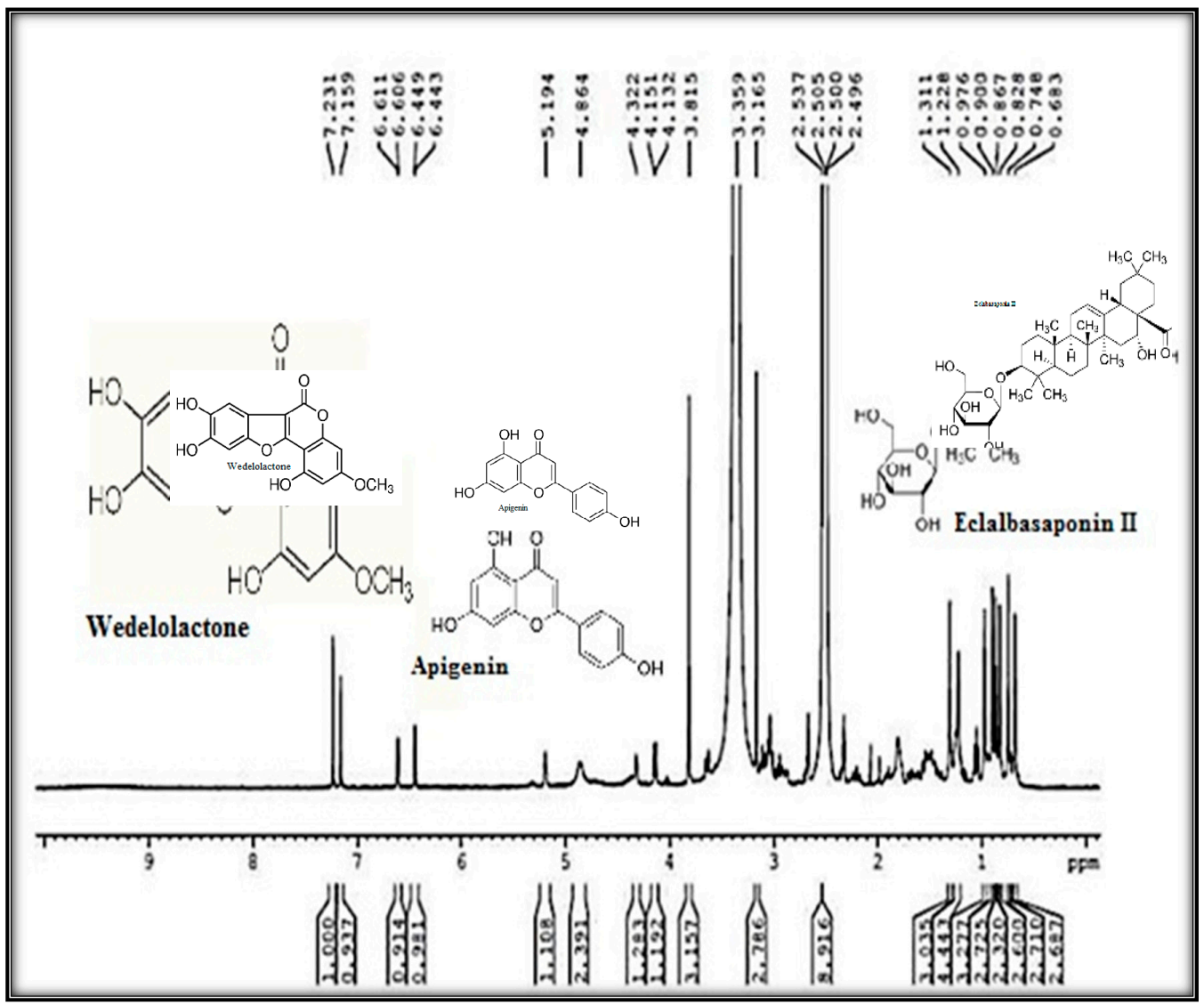

Figure 6. Proton NMR spectra of column-purified antifungal fraction of E. alba.

\section{Discussion}

Sorghum is a staple food for the majority of the economically poor population in India and African countries. The pathogenic fungi lead to loss of germination and low grain yield, thus, posing a severe threat to the economic resources of poor farmers. Further, the fungal infestation in seeds manifests mycotoxin posing health risks and reduces the nutritional quality of grains and makes the grains unfit for human consumption. Several chemical fungicides are available, but the unscientific and indiscriminate use of these fungicides over the years has led to resistance in pathogens and poses 
environmental risks. Further, many farmers cannot afford to use chemical fungicides because of their high cost. This necessitates the investigation of alternative disease control measures, such as botanical fungicides. Seed treatment with E. alba extract has already been shown to reduce fungal infection, enhance growth, and increase the yield of sorghum [20-23]. In this context, the in vitro antifungal potential of pharmacologically important E. alba on economically destructive sorghum grain mold pathogens was evaluated.

Freshly collected E. alba was powdered and extracted sequentially with different polarity solvents by the soxhlet extraction process. Among all the solvent extracts, methanol extract exhibited the highest antifungal activity on target pathogens E. sorghinum, F. thapsinum, C. lunata, and A. alternata. The antibacterial, antifungal, and antiviral activity and pharmacological use of $E$. alba extract were reported by several researchers. The herbal extract zone of inhibition was shown to be equal to or larger than the zone of inhibition of synthetic chemicals [24].

The crude E. alba extract was further purified using column chromatography to remove the possible inactive phyto-compounds and pigments, which could interfere with the antifungal activity. The extract was fractioned based on differential polarity by silica column and the tested for antifungal activity. The methanol fraction exhibited better antifungal potential compared to the crude extract. The elimination of the hexane and ethyl acetate soluble fraction improved the potency of the methanol fraction compared to the crude extract.

The treatment with E. alba extract significantly influenced the germination of sorghum seed. The in vitro germination was evaluated by the between paper method, and a significant difference in germination percentage was observed among the treatments. The germination percentage of E. alba treated seeds remained statistically on par with Bavistin treated seeds. The present study has clearly demonstrated that the seeds treated E. alba extract have improved germination and seedling emergence by suppressing the pathogens. The lower infection could be due to the presence of antifungal metabolites in E. alba that suppress the growth of pathogenic seed-borne fungi. Increased disease protection of E. alba was observed under greenhouse studies, whereas reduced efficacy was noticed in field conditions, which may be due to the leaching the E. alba extract from treated seeds in soil. Further, the stability and persistence of the extract may be a point to address to increase the disease protection in field conditions. With this background, the decision has been taken to formulate the $E$. alba extract with a biodegradable polymer and penetrating agent. The improved disease protection in field conditions was obtained by using the E. alba formulations. Lawsonia inermis and Psoralea corylifolia botanical formulation were prepared based on antifungal tests and greenhouse studies against purple blotch in onion and damping off and Alternaria blight in tomato. The formulation resulted in an increased yield of tomato and onion with reduced disease incidence up to $63 \%$ and $64 \%$ [25]. Formulation of Datura metel extract along with Pseudomonas fluorescens and Bacillus subtilis reduced Fusarium wilt disease incidence caused by Fusarium oxysporum under greenhouse and field conditions with an increased yield of banana [26]. Additionally, E. alba extract proved to be non-toxic towards Sprague Dawley rats and New Zealand white rabbits in oral administration, acute dermal irritation, and eye irritation studies in vitro [4]. Formulations from the study induced significant protection against grain mold diseases. The broad spectrum antifungal activity and efficacy of the purified methanol fraction was investigated for its chemical composition using various chromatographic techniques. The TLC profiling of the purified fraction revealed the presence of saponins, coumestans, and flavonoids which were confirmed by comparing the Rf value with the literature reported values. The results are in line with the phytochemical screening of E. alba methanolic extract and revealed the presence of flavonoids, tannins, saponins, coumestans, and alkaloids [27]. The UPLC chromatographic profile also supported the findings of TLC. The presence of three major categories of compounds, such as saponins, coumestans and flavonoids, in the column purified sample were identified based on the Relative Retention Time (RRT) with respect to wedelolactone. The E. alba phytochemical constituents contained triterpenoid saponins, flavonoids, thiophenes, and steroids [8]. 
Aqueous extract and methanol extract of E. alba inhibited the mycelial growth of Drechslera halodes, Aspergillus niger, F. oxysporum, Aspergillus flavus, Fusarium solani, and Fusarium moniliformae by poisoned food technique [28]. Seed treatment with essential oil of Cymbopogon giganteus, $C$ nardus and C schoenanthus showed reduced incidence of Curoularia sp., Fusarium sp., Phoma sp., Colletotrichum sp. in sorghum and pearl millet [29]. The saponin fraction obtained from E. alba exhibited antimycotic activity against $A$. niger, $A$. flavus and $A$. fumigatus pathogens and the inhibition was on par with antibiotics, such as Amphotericin-B and chloramphenicol [30]. The presence of coumestans and wedelolactone in the ethyl acetate fraction of E. alba showed antimicrobial property against Salmonella typhimurium, Staphylococcus epidermidis, S. aureus, Shigella flexneri and antifungal activity against Aspergillus ochraceus [5,31]. Flavonoid content of E. alba inhibited human pathogens, such as Proteus mirabilis, Bacillus subtilis, Pseudomonas fluorescens, and Staphylococcus aureus [32]. Wedelolactone from E. alba play an important role in the inhibition of S. typhimurium and S. epidermidis, and this compound can be used in treating the above pathogen infections in humans [33]. Eclalbasaponin from E. alba exhibited antibacterial activity against $P$. aeruginosa and $B$. subtilis by disrupting the cell wall of bacteria resulting in loss of bacterial cell viability [24].

The precise identification of the potential antifungal bioactive metabolites in the purified fraction was investigated by UPLC coupled mass spectrometry finger printing. The total ion chromatograph of the extract and mass to charge ratio $(\mathrm{m} / \mathrm{z})$ revealed the presence of apigenin sulfate, apigenin, eclalbasaponin II, ecliptasaponin C, eclalbasaponin VI, and wedelolactone. The presence of eclalbasaponin II and wedelolactone was confirmed by the chemical shift value of NMR.

The chemical characterization of bioactive metabolites revealed the presence of saponins with higher concentrations of eclalbasaponin II and wedelolactone in the purified methanolic fractions of E. alba may lead to loss of pathogen cell viability. Saponins are secondary metabolites stored as inactive precursors in plant cells, when pathogen infects the plant it will alter into a biologically active antibiotic through enzymes $[34,35]$. Saponins along with sterols form a complex in the membrane of fungi and cause a break in the integrity of the cell membrane by inducing transmembrane pores $[36,37]$. $\alpha$-Tomatine, a saponin isolated from Lycopersicon esculentum can induce cell death in F. oxysporum by activation of G-protein signaling pathway and tyrosine kinase leading to elevation in intracellular $\mathrm{Ca}^{2+}$ and reactive oxygen species accumulation [38]. Saponins possess antifungal, antiulcer, antiviral, antibiotic, anti-inflammatory, and hepatoprotective activities [39]. Triterpenic saponin isolated from Diploknema butyracea and Sapindus mukorossi showed antifungal activity against Rhizoctonia bataticola and Sclerotium rolfsii fungal pathogens [40]. The saponin rich extract obtained from Quillja saponaria bark, Yucca schidigera, and Balanites aegyptiaca fruit mesocarp, showed better antifungal activity against Pythium ultimum, Colletotrichum coccodes, Alternaria solani, and Verticillium dahlia [41]. The saponin isolated from E. alba causes disruption of microbial cell membrane resulting in loss of microbial cell viability [42]. Morphological deformation of the Pyricularia oryzae mycelia was observed due to eclalbasaponin II isolated from E. alba [43].

\section{Conclusions}

The results demonstrated antifungal activity of the methanol fractions of $E$. alba on sorghum pathogens, such as F. thapsinum, A. alternata, E. sorghinum and C. lunata. The elimination of the nonpolar soluble from the methanol extract by column purification, improved the antifungal potency of the methanol E. alba extract. The chemical characterization of the bioactive antifungal metabolites revealed the presence of phyto-analogs, such as eclalbasaponin II and wedelolactone, at higher concentrations in methanolic factions of $E$. alba, which significantly contributed to the antifungal activity against target sorghum pathogens. Further, this work substantiated the findings of earlier work [21,22] which has shown the antifungal activity of E. alba extracts against sorghum pathogens. The present study shed light on the use of methanolic E. alba fractions as a potential alternative and cost effective botanical fungicide on economically destructive sorghum grain mold pathogens. 
Supplementary Materials: The following are available online at http:/ www.mdpi.com/2223-7747/8/3/72/s1, Figure S1: Effect of seed treatment with E. alba extract $(120 \mathrm{mg} / \mathrm{mL})$ on emergence of seedlings for seeds infected with (A) Pathogen control (F. thapsinum) (B) Water treated control (C) Bavistin treated (D) F. thapsinum (E) E. sorghinum (F) A. alternata (G) C. lunata, Figure S2: (A) Effect of seed treatment on performance of sorghum in field trials by randomized block design (30 DAS), (B) Effect of seed treatment on performance of sorghum in field trials by randomized block design (60 DAS), Figure S3: UPLC MS/MS full scan m/z 100 -1700 spectra of E. alba column purified sample, Figure S4: Mass chromatography data of (A) Apigenin, (B) Wedelolactone, (C) Eclalbasaponin II, and (D) EclalbasaponinVI, Table S1: Major peaks retention time and peak area of column purified fraction of E. alba at $260 \mathrm{~nm}$.

Author Contributions: R.S.B.-Execution of research work, generation of data, prepared preliminary draft of Manuscript; N.M.-Helped the first author in collection of materials and experimentation. A.C.U.-Research Scientist of the project. Planning of experimental protocols, compilation of data and coordination of work. S.R.N.-Local coordinator of the project. Planning of growth inhibition assay and interpretation of results. O.S.L.-Principal coordinator of the project, overall planning of research and interpretation of data. H.S.P.-Local coordinator of the project. Planning of the work, interaction during experimentation, analysis of the data and interpretation, drafting of MS.

Funding: The work was carried out with the financial assistance under the Europe AID program [grant number DCI-FOOD/2012/304-690].

Acknowledgments: The authors thanks European Union for financial assistance under the Europe AID program and further extend thanks to Venugopal Govindegowda, CMD Rayonnant for his guidance and assistance provided for analytical and formulation development.

Conflicts of Interest: We declare that we have no conflicts of interest to this work.

\section{References}

1. Tian, J.; Ban, X.; Zeng, H.; Huang, B.; He, J.; Wang, Y. In vitro and in vivo activity of essential oil from dill (Anethum graveolens L.) against fungal spoilage of cherry tomatoes. Food Control. 2011, 22, 1992-1999. [CrossRef]

2. Chokotia, L.S.; Vashistha, P.; Sironiya, R.; Matoli, H. Pharmacological Activities of Eclipta Alba (L.). Int. J. Res. Dev. Pharm. Life Sci. 2013, 2, 499-502.

3. Jaglan, D.; Brar, A.S.; Gill, R. Pharmacological activity and chemical constituents of Eclipta alba. Global J. Med. Res. 2014, 13, 35-40.

4. Udayashankar, A.C.; Rajini, S.B.; Nandhini, M.; Suhas, Y.S.; Niranjana, S.R.; Lund, O.S.; Prakash, H.S. Acute oral toxicity, dermal irritation and eye irritation study of Eclipta alba aqueous extract in sprague dawley rats and newzealand white rabbits. Int. Res. J. Pharm. 2016, 7, 103-109. [CrossRef]

5. Dhaka, N.; Kothari, S.L. Micropropagation of Eclipta alba (L.) Hassk-an important medicinal plant. In Vitro Cell. Dev. Biol. Plant 2005, 41, 658-661. [CrossRef]

6. Yahara, S.; Ding, N.; Nohara, T. Oleanane glycosides from Eclipta alba. Chem. Pharm. Bull. 1984, 42, $1336-1338$. [CrossRef]

7. Park, J.W.; Kim, E.K.; Kim, Y.B. Estimation of the daily exposure of Koreans to aflatoxin B1 through food consumption. Food Addit Contam. 2004, 21, 70-75. [CrossRef]

8. Galvano, F.; Piva, A.; Ritieni, A.; Galvano, G. Dietary strategies to counteract the effects of mycotoxins: A review. J. Food Prot. 2001, 64, 120-131. [CrossRef]

9. Marin, S.; Magan, N.; Serra, J.; Ramos, A.J.; Canela, R.; Sanchis, V. Fumonisin B1 production and growth of Fusarium moniliforme and Fusarium proliferatum on maize, wheat, and barley grain. J. Food Prot. 1999, 64, 921-924. [CrossRef]

10. Neergaard, P. Screening for plant health. Annu. Rev. Phytopathol. 1986, 24, 1-17. [CrossRef]

11. Bhat, R.V.; Vasanthi, S. Food Safety in Food Security and Food Trade: Mycotoxin Food Safety Risk in Developing Countries; International Food Policy Research Institute: Washington, DC, USA, 2003.

12. Muro-Cach, C.A.; Stedeford, T.; Banasik, M.; Suchecki, T.T.; Persad, A.S. Mycotoxins: Mechanisms of toxicity and methods of detection for identifying exposed individuals. J. Land Use Environ. Low 2004, 19, 537-556.

13. Wilson, T.; Rabie, C.J.; Fincham, J.E.; Steyn, P.S.; Schipper, M.A. Toxicity of rhizonin A, isolated from Rhizopus microsporus, in laboratory animals. Food Chem. Toxicol. 1984, 22, 275-281. [CrossRef]

14. International Seed Testing Association (ISTA). Proceedings of ISTA International Rules for Seed Testing. Seed Sci. Technol. 2003, 21, 25-30. 
15. Pujol, I.; Guarro, J.; Llop, C.; Soler, L.; Fernández-Ballart, J. Comparison study of broth macrodilution and microdilution antifungal susceptibility tests for the filamentous fungi. Antimicrob. Agents Chemother. 1996, 40, 2106-2110. [CrossRef]

16. Elsherbiny, E.A.; Amin, B.H.; Baka, Z.A. Efficiency of pomegranate (Punica granatum L.) peels extract as a high potential natural tool towards Fusarium dry rot on potato tubers. Postharvest Biol. Technol. 2016, 111, 256-263. [CrossRef]

17. Lee, D.G.; Park, Y.; Kim, H.N.; Kim, H.K.; Kim, P.I.; Choi, B.H.; Hahm, K.S. Antifungal mechanism of an antimicrobial peptide, HP (2-20), derived from N-terminus of Helicobacter pylori ribosomal protein L1 against Candida albicans. Biochem. Biophys. Res. Commun. 2002, 291, 1006-1013. [CrossRef] [PubMed]

18. Han, L.F.; Jing, Z.H.; Zhang, Y.; Agyemang, K.O.; Liu, E.W.; Tao, W.A. Chemical constituents from dried aerial parts of Eclipta prostrata. Chin. Herb. Med. 2013, 5, 313-316. [CrossRef]

19. Prom, L.K.; Perumal, R.; Cissé, N.; Little, C.R. Evaluation of selected sorghum lines and hybrids for resistance to grain mold and long smut fungi in Senegal, West Africa. Plant Health Prog. 2014, 15, 74-77. [CrossRef]

20. Zida, E.P.; Sereme, P.; Leth, V.; Sankara, P. Effect of aqueous extracts of Acacia gourmaensis A. Chev and Eclipta alba (L.) Hassk. on seed health, seedling vigour and grain yield of sorghum and pearl millet. Asian J. Plant Pathol. 2010, 4, 59-66. [CrossRef]

21. Zida, P.E.; Lund, O.S.; Neya, J.B. Seed treatment with a binary pesticide and aqueous extract of Eclipta alba (L.) Hassk. for improving sorghum yield in Burkina Faso. J. Trop. Agric. 2012, 50, 1-7.

22. Zida, P.E.; Neya, B.J.; Soalla, W.R.; Prakash, H.S.; Niranjana, S.R.; Udayashankar, A.C.; Nandini, M.; Rajini, S.B.; Barrocas, E.N.; Andresen, M.; et al. Increased feasibility of treating sorghum seeds with Eclipta alba extract by lowering concentration of plant extract and soaking time of seeds. Int. J. Trop. Agric. 2015, 33, 2391-2400.

23. Zida, P.E.; Neya, B.J.; Soalla, W.R.; Jensen, S.M.; Stockholm, M.S.; Andresen, M.; Kabir, M.H.; Sereme, P.; Lund, O.S. Effect of sorghum seed treatment in Burkina Faso varies with baseline crop performance and geographical location. Afr. Crop Sci. J. 2016, 24, 109-125. [CrossRef]

24. Rios, J.L.; Recio, M.C. Medicinal plants and antimicrobial activity. J. Ethnopharmacol. 2005, 100, 80-84. [CrossRef] [PubMed]

25. Bharathi, S. Developing Botanical Formulations for the Management of Major Fungal Diseases of Tomato and Onion. Doctoral Dissertation, Tamilnadu Agricultural University Coimbatore, Coimbatore, India, 2004.

26. Akila, R.; Rajendran, L.; Harish, S.; Saveetha, K.; Raguchander, T.; Samiyappan, R. Combined application of botanical formulations and biocontrol agents for the management of Fusarium oxysporum $\mathrm{f}$. sp. cubense (Foc) causing Fusarium wilt in banana. Biol. Control 2011, 57, 175-183. [CrossRef]

27. Dalal, S.; Rana, S.; Sastry, K.; Kataria, S. Wedelolactone as an Antibacterial agent extracted from Eclipta alba. Int. J. Microbiol. 2009, 7,1.

28. Hussain, I.; Khan, N.; Ullah, R.; Ahmed, S.; Khan, F.A.; Yaz, S. Phytochemical, physiochemical and anti-fungal activity of Eclipta alba. Afr. J. Pharm. Pharmacol. 2011, 5, 2150-2155.

29. Zida, P.E.; Sereme, P.; Leth, V.; Sankara, P.; Somda, I.; Néya, A. Importance of seed- borne fungi of sorghum and pearl millet in Burkina Faso and their control using plant extracts. Pak. J. Biol. Sci. 2008, 11, 321-331.

30. Kannabiran, K. Antimicrobial activity of saponin fractions of the leaves of Gymnema sylvestre and Eclipta prostrata. World J. Microbiol. Biotechnol. 2008, 24, 2737.

31. Uddin, M.N.; Rahman, M.A.; Ahmed, N.U.; Rana, M.S.; Akter, R.; Chowdhury, A.M.A. Antioxidant, cytotoxic and antimicrobial properties of Eclipta alba ethanol extract. Int. J. Biol. Med. Res. 2010, 1, 341-346.

32. Uddin, J.; Julie, A.S.; Ali, M.H.; Islam, M.N.; Khan, S.A.; Labu, Z.K. Antimicrobial, thrombolytic, membrane stabilizing activities and total flavonoid content of various partitionates of aerial parts of Eclipta alba (L.) Hassk. Dhaka Univ. J. Pharm. Sci. 2015, 14, 207-213. [CrossRef]

33. Dalal, S.; Kataria, S.K.; Sastry, K.V.; Rana, S.V. Phytochemical screening of methanolic extract and antibacterial activity of active principles of hepatoprotective herb, Eclipta alba. Ethnobot. Leafl. 2010, 2010, 3.

34. Arif, T.; Bhosale, J.D.; Kumar, N.; Mandal, T.K.; Bendre, R.S.; Lavekar, G.S.; Dabur, R. Natural products-antifungal agents derived from plants. J. Asian Nat. Prod. Res. 2009, 11, 621-638. [CrossRef]

35. Yang, C.R.; Zhang, Y.; Jacob, M.R.; Khan, S.I.; Zhang, Y.J.; Li, X.C. Antifungal activity of C-27 steroidal saponins. Antimicrob. Agents Chemother. 2006, 50, 1710-1714. [CrossRef]

36. Keukens, E.A.; De Vrije, T.; Van den Boom, C.; De Waard, P.; Plasman, H.H.; Thiel, F.; de Kruijff, B. Molecular basis of glycoalkaloid induced membrane disruption. Biochim. Biophys. Acta 1995, 1240, 216-228. [CrossRef] 
37. Tsuzuki, J.K.; Svidzinski, T.I.; Shinobu, C.S.; Silva, L.F.; Rodrigues-Filho, E.; Cortez, D.A.; Ferreira, I.C. Antifungal activity of the extracts and saponins from Sapindus saponaria L. Anais Acad. Bras. Cienc. 2007, 79, 577-583. [CrossRef]

38. Ito, S.I.; Ihara, T.; Tamura, H.; Tanaka, S.; Ikeda, T.; Kajihara, H.; Dissanayake, C.; Abdel-Motaal, F.F.; El-Sayed, M.A. $\alpha$-Tomatine, the major saponin in tomato, induces programmed cell death mediated by reactive oxygen species in the fungal pathogen Fusarium oxysporum. FEBS Lett. 2007, 581, 3217-3222. [CrossRef]

39. Fenwick, D.E.; Oakenfull, D. Saponin content of soya beans and some commercial soya bean products. J. Sci. Food Agric. 1981, 32, 273-278. [CrossRef]

40. Saha, S.; Walia, S.; Kumar, J.; Parmar, B.S. Structure-biological activity relationships in triterpenic saponins: The relative activity of protobassic acid and its derivatives against plant pathogenic fungi. Pest Manag. Sci. 2010, 66, 825-831. [CrossRef]

41. Chapagain, B.P.; Wiesman, Z.; Tsror, L. In vitro study of the antifungal activity of saponin-rich extracts against prevalent phytopathogenic fungi. Ind. Crops Prod. 2007, 26, 109-115. [CrossRef]

42. Ray, A.; Bharali, P.; Konwar, B.K. Mode of antibacterial activity of eclalbasaponin isolated from Eclipta alba. Appl. Biochem. Biotechnol. 2013, 171, 2003-2019. [CrossRef]

43. Zhao, Y.P.; Tang, H.F.; Jiang, Y.P.; Wang, Z.Z.; Yi, Y.H.; Lei, Q.Y. Triterpenoid saponins from Eclipta prostrata L. Acta Pharmacol. Sin. 2001, 36, 660-663.

(C) 2019 by the authors. Licensee MDPI, Basel, Switzerland. This article is an open access article distributed under the terms and conditions of the Creative Commons Attribution (CC BY) license (http:/ / creativecommons.org/licenses/by/4.0/). 